\title{
Normas para envio de artigos
}

Os textos (artigos, relatos de casos clínicos, relatos pessoais, monografias, teses, resenhas, pesquisas, estudos, comunicação, pontos de vista, carta ao editor) deverão ter: para a sessão Opinião: 3 a 6 laudas.

Para as demais sessões um máximo 10 (dez) páginas que devem estar digitadas com letra Times New Roman, tamanho 12 (doze), espaçamento simples e devem ser enviados por e-mail (gislenefo@hotmail.com) ou pelo Correio (impresso e em CD) para o endereço: Rua profa. Sílvia Ferreira, 442, ap 303 - Piedade, Jaboatão dos Guararapes, CEP: 54.400-530. Pernambuco, Brasil, acompanhados do Formulário Para Envio de Artigos (abaixo).

O envio dos originais, seja por e-mail ou pelos Correios, implica pelo(os) autor(es), automaticamente, na aceitação dos Termos Para Publicação da Id en line REVISTA DE PSICOLOGIA, sem retribuição financeira e assume total responsabilidade pelo seu conteúdo. Os originais impressos e em CD não serão devolvidos.

\section{OBSERVAÇÃO:}

Os Textos para Publicação deverão ser acompanhados por declaração assinada dos autores, nos seguintes termos:

Os autores dos textos enviados asseguram que participaram e se responsabilizam pelo seu conteúdo, bem como pela correta citação de outros autores no corpo do texto. Têm ciência que os trabalhos serão submetidos à revisão da língua portuguesa e que isso poderá implicar em correções sem prejuízo do seu conteúdo. Têm ciência de que todos os trabalhos publicados pela Id on line REVISTA DE PSICOLOGIA, passam a ser de propriedade intelectual do seu Editor. Têm ciência que os manuscritos enviados serão apreciados pelo Editor e poderão ser rejeitados para a publicação. Estão de acordo com a linha editorial desta revista. A responsabilidade dos textos enviados é dos autores que assinam os mesmos. Os autores que enviarem seus textos automaticamente concordam com os Termos Para Publicação.

As questões éticas referentes às publicações de pesquisa com seres humanos são de inteira responsabilidade dos autores e devem estar em conformidade com os princípios contidos na Declaração de Helsinque da Associação Médica Mundial (1964, reformulada em 1975,1983, 1989, 1989, 1996 e 2000).

O Formulário para envio de artigos deverá conter as informações abaixo:

Título

Nome e qualificação do(s) autor(es)

E-mail do(s) autor(es)

Endereço completo d(s) autor(es)

Local (cidade, estado, país) e data

Fone para contato 